\title{
War and society
}

\author{
V. Upeniece \\ Rīga Stradiņš University, Riga, Latvia
}

\begin{abstract}
A discussion of effects of war on society is desirable as it can stimulate nations and their politicians to refrain in their international and non-international relations from the threat or use of force against the territorial integrity or political independence of the state. The prohibition of the use of force is a valid norm of customary international law and is fixed in the Charter of the United Nations. Any specific use of force can be lawful only if it is based on exceptions of this rule (action of self-defence under the Article 51 or action under specific authorization by the Security Council under Chapter VII). However the main issue is how to ensure that the other states respect this principle of non-use of force.
\end{abstract}

Key words: effects of war on society, prevention of an armed conflict

\section{Introduction}

Generally in modern Western countries war is regarded negatively, as a phenomenon that destroys peaceful life of the society and dramatically changes people's lives. Of course, the effects of a war on people are varied and depend on many different factors. There is a point of view that wars stimulate economic growth, because wartime mobilization leads to increased technological innovation. Wars, for example World War II, evoke an increase in the number of jobs available to groups whose participation in the economy had been historically limited (women, minorities).

On the other hand wars bring many negative aspects to society. Primarily, it is negative impact on demographic situation. It is obvious that a big number of people died both in death caused by war and the death caused indirectly by wars related diseases, epidemics and famine. Furthermore, according to research data homicide rates are greater after wars [1]. One of the reasons of such situation is returning of violent veterans to the society after wars and their incapability to stop committing acts of violence. After active duty many veterans who served the country with honour abuse alcohol and drugs. Recent surveys proved that those who undergone particularly stressful experience are at the greatest risk of misusing alcohol [2]. Food shortages created by a war directly influence the future state of children's health. Those who suffered from famine period when they were children are at higher risk of weak immunity system later in their life. Supply shortages related with a war cause prices to rise. There is an opinion that a war dwarfs economic growth, because people are killed and the war triggers the transfer of facilities from the production of peacetime goods to the production of military equipment. On the governmental level a large wartime mobilization can lead to the increase in the governmental centralization. The state develops and maintains institutions specialized on the exercise of coercion [1]. An armed conflict may cause the movement of a large refugee population to the neighbouring countries which are not ready to accept them. 


\section{Discussion}

The most effective tools include diplomatic, economic, informational and military actions. Effective using of all these tools provides a greater effect than employing measures in isolation. The diplomatic measures are considered to be as one of the most important efforts to prevent and resolve conflicts peacefully and to avoid the suffering of a war. The diplomacy may be reinforced by informational and economic measures (for example a combination of inducements and sanctions). The military and informational measures can also reinforce diplomacy when they are used in the way that may help inhibit perpetrator from taking undesired actions (for example, media coverage of deployment preparation to be ready for rapid response or shows of the force that can provide visible displays of military power and convey the message that the country can cause severe damage in the case of necessity of use of force) [3]. Understanding that the Security Council may, if necessary, also take military measures, involving the armed forces of the Member States, if it determines the threat to the peace, breach of the peace or act of aggression, can also deter perpetrator from use of force [4].

Reportedly, one of the measures for the prevention of the threat to the peace that falls within the national competence is criminalization of joining a foreign fight [5]. So as to find adequate ways to confront terrorism and to prevent the potential danger of returning fighters, regional institutions of certain states started to search for measures to prevent their citizens from fighting abroad.

The Criminal Law of the Republic of Latvia contains the definition of terrorism. The financing of terrorism, calling to terrorism, terrorism threat and recruitment and training of persons for the commitment of acts of terror are considered as a crime according to the Criminal Law [6]. In February 2015 the Parliament of the Latvian Republic adopted the amendments to the Criminal Law which prohibit Latvian citizens, non-citizens and foreigners who have a permanent residence permit for the Republic of Latvia, to participate unlawfully in an armed conflict abroad and to collect or transfer financial or other resources for the party of an armed conflict abroad which is fighting against the territorial integrity or political independence of the state or otherwise is acting contrary to the international law binding to the Republic of Latvia. These amendments to the Criminal Law also prohibit recruiting, training and sending persons to unlawful participation in an armed conflict abroad.

According to article $77^{1}$ of the Criminal Law of the Republic of Latvia the unlawful participation in an armed conflict is an active participation in an armed conflict abroad which is taking place against the territorial integrity or political independence of the state or otherwise is contrary to the international law binding to the Republic of Latvia, contrary to the laws and the regulations [laws and regulations of the Republic of Latvia] or to the international agreements binding to the Republic of Latvia.

Two interpretations of this Criminal Law norm can be discussed. According to the article 2 of the law "Participation of the Latvian National Armed Forces in International Operations" Latvian National Armed Forces can participate in international operations within the scope of a mandate approved by the United Nations or another international organization, or in accordance with the international agreements binding to the Republic of Latvia and laws of the Republic of Latvia, as well as a decision of the Parliament of the Latvian Republic, the Cabinet of Ministers or - in the case specifically provided for in the law - the Minister of Defence on participation of the contingent of the Latvian National Armed Forces in international operations. Thereby the lawful way of participation in an armed conflict abroad may be participation as a member of the Latvian National Armed Forces. It is also possible to participate in an international mission as a civilian expert. The civilian experts participate 
in international missions on the basis of such international organization, union or community resolutions, recommendations or requests with which the Republic of Latvia had made an international agreement, as well as on the basis of the request of the European Union or the North Atlantic Treaty Organization. The Cabinet of Ministers makes a decision on the participation of the civilian experts in an international mission [7]. The Border Guards Law, the Law on Police and the Fire Safety and Fire-fighting Law provide similar provisions for the participation in international missions of border guards, police officers and state specialized civil servants serving in the State Fire-fighting and Rescue Service [8-10]. So far as there is no another law that can provide an order of lawful participation in an armed conflict abroad it becomes impossible to participate in such conflicts, for example, as a member of the armed forces created by any country for foreign nationals willing to serve in the armed forces of this country.

The other risk for those who plan participation in an armed conflict abroad is mentioned in the Citizenship law, according to which the citizenship can be revoked if the person serves voluntary in the armed forces or military organisation of other country without an authorisation of the Cabinet of Ministers except the case when the person is serving in the armed forces or a military organisation of a Member State of the European Union, a Member State of the European Free Trade Association, a Member State of the North Atlantic Treaty Organisation, the Commonwealth of Australia, the Federative Republic of Brazil, New Zealand or in the armed forces or military organisation of a country with which the Republic of Latvia had made an agreement regarding recognition of dual citizenship, without permission from the Cabinet and in the case of revocation of Latvian citizenship the person does not become a stateless person [11]. For those, who had obeyed this obligation to receive authorisation of the Cabinet of Ministers, the above mentioned Criminal Law total prohibition of participation in armed conflicts abroad can cause misunderstanding of correct behaviour. The above mentioned regulation means that the person who serves in the armed forces of, for example, a Member State of the European Union or who had received an authorization of the Cabinet of Ministers to serve in the armed forces of some other country which does not fall within the list of exceptions, has to refuse to carry out the order of the superior to participate in the military operation in a zone of an armed conflict abroad which is taking place against the territorial integrity or political independence of the state or otherwise is contrary to the international law binding to the Republic of Latvia.

The other interpretation of Criminal Law amendments that can take place is the following - the criminal liability cannot be arisen if the person participates in an armed conflict abroad as a member of the armed forces of the state that defends its territorial integrity or political independence. In such situation the argument to justify participation in an armed conflict can be that the person participated in an armed conflict abroad which was taking place with the aim to protect the territorial integrity or political independence of the state. However the article $77^{1}$ of the Criminal Law doesn't emphasize the importance of being a member of a certain party of an armed conflict (acting against the state interests or protecting the state interests) for detecting a crime.

According to the Criminal Law amendments criminal liability can be also imposed if the person collects or transfers financial resources or other property for or to the party of an armed conflict abroad which is acting against the territorial integrity or political independence of the state or otherwise is acting contrary to the international law binding to the Republic of Latvia, as well as for recruitment, training or sending of persons for unlawful participation in an armed conflict abroad. Thereby the cited article $77^{2}$ of the Criminal Law accents the prohibition of support of the party of an armed conflict abroad which is acting against the certain interests of the state. 
The additional contribution to maintenance of peace and stability is the article $77^{3}$ of the Criminal Law according to which the personal recruitment, training or sending to unlawful participation in an armed conflict abroad is considered as a crime. As it was mentioned before the definition of unlawful participation in an armed conflict abroad is given in the article $77^{1}$ of the Criminal Law.

\section{Conclusion}

A war alters dramatically lives of all people who live in the country that is the party of an armed conflict. Participation in peacekeeping or peace enforcement operations can cause physical and psychological wounds on soldiers and their families. A war has its indirect negative influence also on the other countries that accept refugees.

The situations that arise in the modern world acknowledge that the international law is imperfect and cannot always ensure solutions that would prevent future conflict. The failure to solve the conflict peacefully is often explainable with lack of political will or is a result of ineffective policy processes. The international law may be enfeebled by different political interpretations, particularly when some of the regulations for any reason do not satisfy the interests of the state. That's why the measures of prevention of the threat to the peace incorporated in domestic legal regime may be more successful in the prevention of the treat to the peace.

In February 2015 the Parliament of the Latvian Republic adopted the amendments to the Criminal Law. According to the annotation of the amendments to the Criminal Law the aim of them is to prevent the illegal engagement of nationals in armed conflicts abroad which are taking part against the territorial integrity or political independence of the state or otherwise are contrary to the international law binding to the Republic of Latvia [12]. Admittedly there is no law that can provide a complete solution to all the specific situations that can provide the reality. But the effectiveness of international and domestic law depends on the extent to which their implementation in practice had been achieved by the state.

\section{References}

[1] G. Ausenda, Effects of War on Society, Center for Interdisciplinary Research on Social Stress, San Marino (R.S.M.), 212 (2002).

[2] E. Jones, NT. Fear, Alcohol use and misuse within the military: A review, International Review of Psychiatry, 23(2), 166 (April 2011).

[3] D. Raymond, C. Bernath, D. Braum, Mass atrocity prevention and response options (MAPRO): a policy planning handbook, U.S. Army Peacekeeping and Stability Operations Institute, Carlisle, Pennsylvania, 81, 85, 103-110, 115 (2012).

[4] Charter of the United Nations, available at http://www.un.org/en/documents/ charter/chapter7.shtml

[5] E. Bakker, C. Paulussen, E. Entenmann, Dealing with European Foreign Fighters in Syria: Governance Challenges \& Legal Implications, ICCT Research paper, December, 7 (2013).

[6] Criminal Law [Krimināllikums], viewed 31 March 2015, available at http://likumi.1v//ta/id/88966?\&search= on (in Latvian).

[7] Law on International Assistance [Starptautiskās palīdzības likums], viewed 31 March 2015, available at http://likumi.lv/doc.php?id=175254 (in Latvian).

[8] Border Guards Law [Robežsardzes likums], viewed 31 March 2015, available at http://likumi.lv/doc.php?id=46228 (in Latvian). 
[9] Law on Police [likums "Par policiju"], viewed 31 March 2015, available at http://likumi.lv//ta/id/67957?\&search= on (in Latvian).

[10] Fire Safety and Fire-fighting Law [Ugunsdrošīibas un ugunsdzēsības likums], viewed 31 March 2015, available at http://likumi.lv/ta/id/68293-ugunsdrosibasun-ugunsdzesibas-likums (in Latvian).

[11] Citizenship Law [Pilsonības likums], viewed 31 March 2015, available at http://likumi.lv/doc.php?id=57512\&search= on (in Latvian).

[12] Annotation of the amendments to the Criminal Law [Likumprojekta "Grozījums Krimināllikumā” sākotnējās ietekmes novērtējuma ziņojums (anotācija)], viewed 31 March 2015, available at http://titania.saeima.lv/LIVS12/SaeimaLIVS12. nsf /0/47765D4DD0FD4736C2257DD3002AF17A?OpenDocument (in Latvian). 